\title{
ANALISIS FAKTOR - FAKTOR YANG MEMPENGARUHI KEMISKINAN DI INDONESIA SELAMA LIMA TAHUN TERAKHIR (Studi Kasus Pada 33 Provinsi)
}

\author{
Noor Zuhdiyaty \\ Alumni Program Pascasarjana Ilmu Ekonomi Fakultas Ekonomi dan Bisnis Universitas Brawijaya \\ David Kaluge \\ Dosen Pascasarjana Universitas Brawijaya
}

\section{ABSTRAKSI}

Pembangunan suatu negara adalah hal yang paling utama dilakukan untuk mensejahterakan masyarakat. Salah satu hal yang merupakan tolak ukur pembangunan adlah dengan berkurangnya angka dan pengangguran. Tujuan dari penelitian ini adalah untuk mengetahui faktor-faktor yang mempengaruhi kemiskinan di Indonesia selama kurun waktu lima tahunan 2011-2015. Penelitian ini menggunakan pendekatan kuantitatifdengan uji regresi. Penelitian ini dilakukan pada 33 provinsi yang ad a di Indonesia. Hasil penelitian menunjukkan bahwa adanya pengaruh antara IPM dengan kemiskinan, sedangkan untuk pertumbuhan ekonomi dan TPT tidak memiliki pengaruh terhadap kemiskinan.

Key Word : Kemiskinan, Pertumbuhan Ekonomi, IPM, TPT.

\section{PENDAHULUAN}

Pembangunan adalah tujuan dari sutau negara, dimana negara tersebut semakin maju ketika ada peningkatan pada pembangunannya. Salah satu indikator keberhasilan pembangunan adalah dengan meningkatnya pertumbuhan ekonomi, diharapkan dengan pertumbuhan ekonomi yang tinggi mampu mengurangi pengangguran ataupun kemiskinan yang ada (Rustam 2010). Selain pertumbuhan ekonomi salah satu aspek yang digunakan untuk melihat kinerja pembangunan ekonomi adalah seberapa besar efektifitas penggunaan sumber daya yang tersedia(Yacoub 2012).

Kemiskinan sendiri pada negara berkeembang merupakan masalah yang cukup rumit meskipun beberapa negara berkembang telah berhasil melaksanakan pembangunan dalam hal produksi dan pendapatan nasional (Sartika et al. 2016). Kondisi kemiskinan suatu negara atau daerah juga merupakan cerminan dari tingkat kesejahteraan penduduk yang tinggal pada negara/daerah tersebut (Christianto, 2013) . Indonesia adalah negara yang tergolong masih berkembang dan kemiskinan merupakan masalah yang masih menjadi perhatian.

Pratama ( 2014) mengatakan bahwa Indonesia sebagai negara berkembang yang sudah berumur 57 tahun, masih mengalami masalah kemiskinana sebesar 24\% jika angka kemiskinan di bawah 1\$US dari 240 juta jiwa. Namun, jika angka kemiskinan menggunakan standart hidup dibawah $2 \$$ maka angka kemiskinan tersebut melonjak menjadi 35\%. Pembangunan ekonomi Indonesia saat ini dirasa masih kurang efektif dalam menangani masalah kemiskinan yang ada.

Hal tersebut terlihat dalam laporan BPS pada bulan september 2016 bahwa presentase penduduk miskin perkotaan turun dari 7,79\% menjadi 7,73\% sementara pada daerah perdesaan turun dari 14,11\% menjadi 13,96\%. Namun meskipun demikian jumlah penduduk miskin perkotaan naik sebesar 0.15 juta orang. Selain itu masih adanya provinsi yang memiliki presentase kemiskinan diatas presentase nasional. Hal tersebut menandakan bahwa masih adanya angka kemiskinan yang tinggi yang terjadi pada daerah provinsi yang ada di Indonesia.

Masih adanya tingkat kemiskinan yang terjadi pada daerah Indonesia, maka dari itu penulis ingin meneliti terkait faktor-faktor yang mempengaruhi kemiskinan di Indonesia dengan studi pada 33 provinsi kurun waktu 2011-2015.

\section{KAJIAN PUSTAKA}

Kemiskinan dipandang sebagai ketidakmampuan dari sisi ekonomi untuk memenuhi kebutuhan dasar makanan dan bukan makanan yang diukur dari sisi pengeluaran (BPS). Kemiskinan merupakan masalah yang dihadapi oleh semua negara. Pertumbuhan ekonomi sebagai salah satu indikator dalam mengatasi masalah kemiskinan, dimana pertumbuhan ekonomi merupakan konsep dari pembangunan ekonomi (Atalay 2015).

Berbagai studi empiris yang telah ada menunjukkan bahwa harapan pembangunan ekonomi adalah untuk membawa perbaikan ekonomi, seperti pengentasan kemiskinan, standart pendidikan yang lebih baik atau perbaikan kesehatan (Cremin \& Nakabugo 
2012). Pertumbuhan ekonomi sendiri dapat menjadi kekuatan pendorong untuk menghasilkan kekayaan yang nantinya akan menetes kebawah untuk memberantas kemiskinan dan semua masalah yang menyertainya (Cremin \& Nakabugo 2012). Pendidikan merupakan investasi yang dapat menunjang pertumbuhan ekonomi. Mendidik anak-anak miskin memiliki peluang yang tinggi untuk membawa mereka keluar dari kemiskinan (World Bank).

Salah satu indikator pendidikan dapat dilihat dari tingkat IPM. IPM merupakan indeks komprehensif sebagai ciri tingkat pembangunan manusi disuatu daerah atau negara yang diukur dari tingkat pendidikan, kesehatan dan umur panjang, serta pendapatan (Yakunina RP \& Bychkov GA 2015). IPM menurut BPS ada tiga dimensi yaitu umur panjang dan hidup sehat, pengetahuan dan standar hidup yang layak. Kesehatan datang sebagai konsep dari bagian modal manusia sebagai bukti dampak panjang pada pertumbuhan ekonomi seperti halnya yang terjadi di Inggris 200 tahun terakhir (Hafner \& Mayer-Foulkes 2013).

Disisi lain pengangguran merupakan salah satu penyebab kemiskinan. Pengangguran, setengah menganggur atau kurangnya lahan produktif sebagai aset penghasil pendapatan merupakan hal yang akut bagi masyarakat miskin ketika dalam memeroleh kebutuhan paling dasar untuk makanan, air dan tempat tinggal adalah hal yang harus diperjuangkan pada setiap harinya (world bank).

Agar kemiskinan tidak semakian akut, maka pemerintah harus meletakkan kemskinan menjadi pusat perhatian, beberapa ahli menyebutkan bahwa penanggulangan kemiskinan yang paling jitu adalah dengan menciptakan aktivitas ekonomi pada daerah guna menciptakan pertumbuhan ekonomi (Yacoub 2012). Pertumbuhan ekonomi yang ada nantinya diharapkan dapat membuka lapangan kerja baru sehingga berkurangnya pengangguran yang ada, serta meningkatkan kualitas hidup masyarakat yang nanti akan dapat mengurangi kemiskinan yang ada.

\section{METODE PENELITIAN}

Penelitian ini dilaksanakan di Indonesia dengan sampel 33 provinsi. Pendekatan dalam penelitian ini adalah kuantitatif dengan data sekunder. Sumber data dari penelitian ini adalah Badan Pusat Statistik (BPS) Indonesia. Periode waktu yang digunakan selama lima tahun yaitu 2011-2015. Adapun teknik pengumpulan data dilakukan secara dokumentasi yakni berdasarkan pengamatan terhadap kajian literatur, buku-buku, jurnal, dsb. Alat analisis yang digunakan adalah regresi data panel. Pertama dilakukan uji Chow untuk menentukan model masuk dalam common effect ataupun fixed effect, kedua dilakukan uji Hausman untuk menentukan model masuk dalam fixed effect ataupun random effect. Ketiga uji tersebut dilakukan untuk menentukan mana model terbaik yang akan digunakan.

Variabel yang digunakan dalam penelitian ini adalah variabel kemiskinan, pertumbuhan ekonomi, Indeks pembangunan manusia (IPM) dan Tingkat pengangguran terbuka (TPT). Model yang digunakan adalah :

Kemiskinan $=\alpha+\beta 1$.Pertumbuhanekonomi $+\beta 2 . T P T+\beta 3 . I P M+e$

Adapun definisi operasionalnya antara lain

1. Kemiskinan presentase kemiskinan setiap provinsi yang sudah penjumlahan total antara kemiskinan yang terjadi di perkotaan dan perdesaan.

2. Pertumbuhan ekonomi presentase pertumbuhan ekonomi atas dasar harga konstan pada setiap provinsi.

3. Tingkat Pengangguran Terbuka (TPT)

Tingkat pengangguran terbuka dari masingmasing provinsi di Indonesia

4. Indeks Pembangunan Manusia (IPM)

Indeks pembangunan manusia dengan metode penghitungan baru yang telah diterbitkan oleh BPS.

\section{HASIL DAN PEMBAHASAN}

Pada gambar dibawah ini dpat dilihat presentase kemiskinan yang terjadi pada 33 provinsi yang ada di Indonesia. Gambar tersebut menunjukkan bahwa angka kemiskinan pada beberapa provinsi berada diatas angka kemiskinan nasional. Diantaranya Aceh, Sumatera Selatan, Bengkulu, Lampung, Jawa Tengah, DIY, Jawa Timur, NTB, NTT, Sulawesi Tengah, Gorontalo, Maluku, Papua Barat dan Papua.

Gambar 1. Presentase Kemiskinan 33 Provinsi di Indonesia Tahun 2015

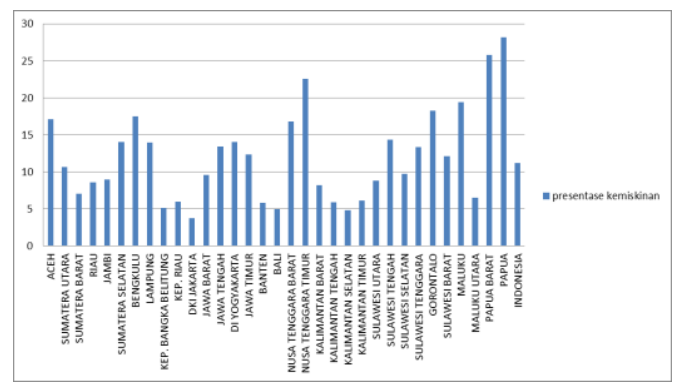

Sumber : BPS (data diolah oleh penulis) 
Hasil penelitian dengan uji Chow menunjukkan bahwa tingkat probabilitas P-value atau probabilitas dari c-square dan $\mathrm{f}$ test adalah 0.0000 yang berarti pada $\alpha 5 \%$ atau 0.05 , maka $p$ value $<\alpha$ atau $0.000<0.05$ yang berarti hasil uji menandakan bahwa $H_{0}$ ditolak dan $H_{1}$ diterima sehingga model yang terpilih adalah fixed effect. Hasil tersebut dapat dilihat pada tabel dibawah ini.

\begin{tabular}{lrrr}
$\begin{array}{l}\text { RedundantFixed Effects Tests } \\
\text { Equation:Untitled } \\
\text { Test cross-section fixed effects }\end{array}$ & & & \\
\hline \hline Effects Test & Statistic & d.f. & Prob. \\
\hline \hline Cross-section F & 58.953428 & $(32,129)$ & 0.0000 \\
Cross-section Chi-square & 453.554472 & 32 & 0.0000
\end{tabular}

Sumber : Hasil ouput regresi data panel dengan regresi eviews 7.0

$\mathrm{H}_{0}=$ model mengikuti pooled leasts quare

$\mathrm{H}_{1}=$ model mengikuti fixed effect

Sementara pada uji Hausman p-value atau hasil probabilitas sebesar 0.0040 dengan tingkat kesalahan $\alpha 5 \%$ atau 0.05 maka $p$-value $<\alpha$ atau $0.0040<0.05$. Sehingga model yang dipilih adalah model fixed effect. Hal tersebut dapat dilihat pada tabel dibawah.

Tabel 1. Hasil Uji Hausman

Correlated Random Effects - Hausman Test

Equation:Untitled

Test cross-section random effects

\begin{tabular}{llll}
\hline \hline Test Summary & $\begin{array}{l}\text { Chi-Sq. } \\
\text { Statistic }\end{array}$ & Chi-Sq. d.f. & Prob. \\
\hline \hline Cross-section random & 13.343041 & 3 & 0.0040 \\
\hline
\end{tabular}

Sumber : Hasil ouput regresi data panel dengan regresi eviews 7.0

$\mathrm{H}_{0}=$ model mengikuti fixed effect

$\mathrm{H}_{1}=$ model mengikuti random effect

Berdasarkan dari uji Chow dan uji

Hausman maka model yang digunakan dalaam penelitian ini adalah uji Hausman yaitu menggunakan fixed effect. Selanjutnya dianalis is menggunakan regresi.

Cross-section random

Dependent Variable: KEMISKINAN

Method: Panel Least Square

Date: 01/09/17 Time: 07:35

Sample: 20112015

Cross-sections included: 33

Total panel (balanced) observations: 16

\begin{tabular}{crrrr}
\hline Variable & Coefficient & Std. Error & t-Statistic & Prob. \\
\hline C & 31.85663 & 8.328509 & 3.825010 & 0.0002 \\
PERTUMEKONOMI & -0.028355 & 0.050984 & -0.556153 & 0.5791 \\
TPT & $-1.12 E-05$ & 0.000507 & -0.022126 & 0.9824 \\
IPM & -0.289890 & 0.123236 & -2.352315 & 0.0202 \\
\hline \multicolumn{5}{c}{ Effects Specification }
\end{tabular}

\begin{tabular}{lrll}
\hline \hline Cross-section fixed (dummy variables) & \\
\hline \hline R-squared & 0.964840 & Mean dependent var & 12.15121 \\
Adjusted R-squared & 0.955300 & S.D. dependent var & 6.371846 \\
S.E. of regression & 1.347157 & Akaike info criterion & 3.624100 \\
Sum squared resid & 234.1133 & Schwarz criterion & 4.301761 \\
Log likelihood & -262.9883 & Hannan-Quinn criter. & 3.899186 \\
F-statistic & 101.1405 & Durbin-Watson stat & 2.928494 \\
Prob(F-statistic) & 0.000000 & & \\
\hline \hline
\end{tabular}

Sumber : Hasil ouput regresi data panel dengan regresi eviews 7.0

Berdasarkan hasil uji regresi dengan metode fixed effect maka pada tabel diatas dapat dilihat bahwa pertumbuhan ekonomi memiliki nilai konstanta sebesar -0.028355 dengan probabilitas sebesar $0.5791>$ 0.05. pertumbuhan ekonomi memiliki nilai negatif tidak signifikan, yang berarti pertumbuhan ekonomi tidak berpengaruh terhadap tingkat kemiskinan. TPT memiliki nilai konstanta sebesar -1.12E-05 dengan probabilitas sebesar $0.9824>0.05$. TPT memiliki nilai negatif tidak signifikan, yang berarti TPT tidak berpengaruh terhadap kemiskinan. Sedangkan untuk IPM memiliki probabilitas sebesar 0.0202 $<0.05$. IPM memiliki nilai positif signifikan, yang berarti IPM berpengaruh terhadap kemiskinan.

Pada tabel 3 dapat dilihat bahwa uji $\mathrm{f}$ statistik dengan nilai $0.0000<0.05$ maka variabel independen secara bersama-sama dapat menjelaskan variabel dependen. Sementara pada uji koefisien determinasi $\mathrm{R}^{2}$ dengan nilai sebesar 0.96840 mengartikan bahwa variabel 96,84\% variasi tingkat kemiskinan dapat dijelaskan oleh variabel independent dalam model yaitu pertumbuhan ekonomi, IPM, TPT. Sedangkan 3,16\% dapat dijelaskan oleh variabel lain.

\section{INTERPRETAS I HASIL}

Berdasarkan hasil uji diatas maka dapat dilihat bahwa IPM berpengaruh negatif signifikan terhadap kemiskinan sebesar 0.289890. Hal tersebut menandakan bahwa antara IPM dengan kemiskinan memiliki hubungan terbalik, yaitu ketika IPM mengalami penurunan sebesar 1 persen dapat menaikkan kemiskinan sebesar -0.289890 , begitu sebaliknya. Hal ini sama dengan penelitian (Rustam 2010) dan (Pratama, 2014) yang menunjukkan bahwa IPM berpengaruh negatif terhadap kemiskinan

Sementara pada pertumbuhan ekonomi tidak berpengaruh signifikan terhadap kemiskinan. Hal ini sama dengan penelitian yang dilakukan oleh (Barika 2013) hal ini mengindikasikan bahwa pertumbuhan ekonomi yang ada lebih banyak ditopang oleh konsumsi 
daripada investasi atau modal. Pertumbuhan ekonomi yang tidak berpengaruh tersebut mencerminkan kurangnya kualitas pertumbuhan ekonomi yang ada karena masih tidak mampu dalam mengurangi kemiskinan. Namun penelitian ini berbeda dengan yang dilakukan oleh (Rustam 2010) yang menunjukkan bahwa pertumbuhan ekonomi berpengaruh negatif signifikan terhadap kemiskinan.

TPT juga tidak berpengaruh terhadap kemiskinan, hal ini sama dengan penelitian yang dilakukan oleh (Ketut \& Endrayani 2016). Hal tersebut mengindikasikan bahwa tidak semua yang menganggur adalah masyarakat miskin, atau mereka yang menganggur masih dihidupi oleh orang yang memiliki pendapatan yang cukup. Namun penelitian ini berbeda dengan yang dilakukan oleh (Yacoub 2012) yang menunjukkan hasil bahwa pengangguran berpengaruh negatif terhadap kemiskinan. Selain itu penelitian ini juga berbeda dengan penelitian yang dilakukan oleh (Barika 2013) yang menunjukkan hasil bahwa pengangguran berpengaruh positif terhadap kemiskinan.

\section{KESIMPULAN}

Hasil penelitian menunjukkan bahwa variabel independent pertumbuhan ekonomi, TPT, dan IPM berpengaruh secara simultan/bersama-sama terhadap variabel dependent kemiskinan dapat dilihat dari nilai $f$ statistik < 0.05. Pada nilai $\mathrm{R}^{2}$ sebesar 0.96840 menjaskan bahwa variabel independent dapat menjelaskan 96\% dari variabel dependent dan sisanya dijelaskan oleh variabel lain.

Pertumbuhan ekonomi, TPT, dan IPM memiliki hubungan yang negatif terhadap kemiskinan. Diantara ketiga variabel tersebut hanya variabel Ipm yang berpengaruh terhadap kemiskinan. Sementara pertumbuhan ekonomi tidak berpengaruh terhadap kemiskinan, hal ini menunjukkan bahwa pertumbuhan yang ada kurang berkualitas sehingga tidak mempengaruhi kemiskinan. Begitu juga dengan pengangguran bahwa tingkat TPT juga tidak berpengaruh terhadap kemiskinan, hal ini menandakan bahwa mereka yang menganggur belum tentu memiliki pendapatan yang rendah.

\section{DAFTAR PUSTAKA}

1. Atalay, R., 2015. Science Direct The education and the human capital to get rid of the middle-income trap and to provide the economic development. Procedia Social and Behavioral Sciences, 174, pp.969-976. Available at: http://dx.doi.org/10.1016/j.sbspro.2015.01.7
20.

2. Barika, 2013. Pengaruh Pertumbuhan Ekonomi, Pengeluaran Pemerintah, Pengangguran Dan Inflasi Terhadap Tingkat Kemiskinan Di Provinsi Se Sumatera. Jurnal Ekonomi dan Perencanaan Pebangunan, 5(3), pp.27-36.

3. Cremin, P. \& Nakabugo, M.G., 2012. Education, development and poverty reduction: A literature critique. International Journal of Educational Development, 32(4), pp.499-506. Available at:

http://dx.doi.org/10.1016/j.ijedudev.2012.0 2.015 .

4. Hafner, K.A. \& Mayer-Foulkes, D., 2013. Fertility, economic growth, and human development causal determinants of the developed lifestyle. Journal of Macroeconomics, 38(PA), pp.107-120. Available at: http://dx.doi.org/10.1016/j.jmacro.2013.04. 001.

5. Ketut, N. \& Endrayani, E., 2016. ANALISIS FAKTOR-FAKTOR YANG MEMPENGARUHI TINGKAT KEMISKINAN KABUPATEN / KOTA DI PROVINSI BALI Fakultas Ekonomi dan Bisnis Universitas Udayana (Unud ), Bali , Indonesia Kesenjangan ekonomi atau ketimpangan distribusi pendapatan antara kelompok masyarakat . , 1, pp.63-88.

6. Online.diakses 15 Desember 2016. http://siteresources.worldbank.org/INTPOV ERTY/Resources/3356421124115102975/15551991124115187705/ch2.pdf

7. Online. diakses 15 Desember 2016. http://www.bps.go.id/Subjek/view/id/23\#s ubjekViewTab1 |accordion-daftar-subjek1

8. Online.diaskes 03 November 2016. https://www.bps.go.id/linkTableDinamis/vi ew/id/1219

9. Pratama, Ci.Y., 2014. Analisis faktor faktor yang mempengaruhi kemiskinan di Indonesia. Bisnis dan Manajemen, 4(September), pp.210-223.

10. Rustam, 2010. Perencanaan Pertumbuhan Ekonomi Jawa Timur Dalam Rangka Mengurangi Angka Pengangguran Dan Kemiskinan. , 6(1).

11. Sartika, C. et al., 2016. No Title. , 1(April), pp.106-118.

12. Teddy Christianto, 2013. Volume VII, No. 2, Desember 2013 ISSN : 1978 - 3612. Determinan dan karakteristik kemiskinan di provinsi Riau, VII(2).

13. Yacoub, Y., 2012. Pengaruh Tingkat 
Pengangguran terhadap Tingkat Kemiskinan Kabupaten / Kota di Provinsi Kalimantan Barat. Jurusan Ilmu Ekonomi Fakultas Ekonomi Universitas Tanjungpura Pontianak, 8(3), pp.176-185.

14. Yakunina RP \& Bychkov GA, 2015. ScienceDirect Correlation Analysis Of The Components Of The Human Development Index Across Countries. Procedia Economics and Finance, 24(July), pp.766771. Available at: http://dx.doi.org/10.1016/S22125671(15)00692-9. 